\title{
The roles of basophils, TSLP and IL-33 in food allergy following epicutaneous sensitisation
}

\author{
Tomohiro Yoshimoto ${ }^{*}$, Taichiro Muto, Ayumi Fukuoka, Kazufumi Matsushita \\ From Food Allergy and Anaphylaxis Meeting 2014 \\ Dublin, Ireland. 9-11 October 2014
}

Cutaneous sensitization with a food antigen before its consumption elicits the development of food allergy. Here we report the site and stage dependent roles of basophils and pro-allergic cytokines, thymic stromal lymphopoietin (TSLP) and IL-33, in a mouse model of food allergy initially sensitized cutaneously with the food antigen. Mice are epicutaneously sensitized with the food antigen ovalbumin (OVA) followed by oral challenge with OVA. Epicutaneously-sensitized mice produce OVA-specific IgE and develop IgE-dependent anaphylaxis after oral challenge. If OVA is given orally before epicutaneous administration, development of food allergy is prevented with Foxp3 mRNA up-regulation. Thus, our mouse model clearly reflects the "dual-allergen-exposure hypothesis" in which allergic sensitization results from cutaneous food antigen exposure before its consumption. When allergy is induced by epicutaneous sensitization then oral challenge, basophil-depleted or TSLP-receptordeficient mice do not produce OVA-specific IgE and are protected from oral challenge-induced anaphylaxis. IL-33deficient mice produce normal levels of OVA-specific IgE, however, IL-33-deficient mice and mice treated with recombinant soluble IL-33 receptor are protected from anaphylaxis. Thus, basophils and TSLP have pivotal roles in Th2 development in the skin during the sensitization phase of food allergy. In contrast, while IL-33 is dispensable for promoting cutaneous antigen sensitization, the cytokine is essential for inducing IgE-dependent anaphylaxis in the gut.

Published: 30 March 2015

doi:10.1186/2045-7022-5-S3-017

Cite this article as: Yoshimoto et al:: The roles of basophils, TSLP and

IL-33 in food allergy following epicutaneous sensitisation. Clinical and

Translational Allergy 2015 5(Suppl 3):O17.

Hyogo College of Medicine, Nishinomiya, Japan

Submit your next manuscript to BioMed Central and take full advantage of:

- Convenient online submission

- Thorough peer review

- No space constraints or color figure charges

- Immediate publication on acceptance

- Inclusion in PubMed, CAS, Scopus and Google Scholar

- Research which is freely available for redistribution
() Biomed Central

(C) 2015 Yoshimoto et al; licensee BioMed Central Ltd. This is an Open Access article distributed under the terms of the Creative Commons Attribution License (http://creativecommons.org/licenses/by/4.0), which permits unrestricted use, distribution, and reproduction in any medium, provided the original work is properly cited. The Creative Commons Public Domain Dedication waiver (http://creativecommons.org/publicdomain/zero/1.0/) applies to the data made available in this article, unless otherwise stated. 